\title{
実験肝障害ラットの凝固系に対する局所用 トロンビン腹腔内注射の影響
}

一トロンビン局所療法による DIC 惹起の可能性について一

\author{
石井 秀美，久保木正明，大倉 実 \\ 平石さゆり，坪内 二郎 \\ 帝京大学薬学部臨床生化学教室* \\ 風間 睦美 \\ 帝京大学医学部第一内科** \\ (昭和59年11月 9 日 [特〕)
}

\begin{abstract}
要約 : 局所用トロンビンは局所的止血剂としての有効性が知られているが，本剂使用後稀てショック，ア ナフィラキシーあるいは沉発性血管内血液凝固症候群 (DIC) の合併をみることが報告された，凝固因子 であるトロンビンは, 血流中への流入によりDIC を惹起する可能性がある. 本研究では腹腔内にトロン ビンを注入した際に DIC が起る可能性につき, ラットを用いて実験的に検討した. 体重 $200 \mathrm{~g}$ ウィスタ 一系ラットに四塩化炭素 $0.12 \mathrm{ml} /$ 匹を週 2 回, 12 週腹腔内注射して肝硬变を, 四塩化炭素 $0.30 \mathrm{ml} /$ 匹の 1 回腹腔内注射により急性肝障害を作成した。 これらに種々の量のトロンビン局所用（Parke-Davis）を 腹腔内注射し, 90 分までの種々の時点で心採血, 屠殺して各種凝血学的検査を行なった. 未処置対照群お よび肝硬変群では血小板数の一過性の増加をみたのみでフィブリノーゲン, プロトロンビン時間 (PT), 活性化部分トロンボプラスチン時間 (APTT) には有意の変動を認めなかった. 四塩化炭素注射後24時間 あるいは48時間後の急性肝障害群につき同様に檢討すると，血小板やフィブリノーゲンの減少，PT およ び APTT の延長が認められ，ことに48時間群でこの傾向が著しかった．また48時間群にトロンビン局所 用 $20,100,1,000 \mathrm{U} / 100 \mathrm{~g}$ を注入すると用量依存性に上記の指標が変動し, 血清 GPT 值も用量依存性 に上昇した. 一方本製剤からトロンビンを除去した非トロンビンタンパク分画（トロンビン $900 \mathrm{U}$ 相当） を48時間群に注射すると上述の諸指標はほとんど変化せず，GPT の上昇のみが認められた．以上の成績 から腹水を貯留する程度の急性肝障害では腹膜の透過性立進のために腹腔内に注入されたトロンビンが血 流中に侵入して，DIG 様の凝血学的所見を現わしたと考兄られたが，臨床的にみられる烈しいショック や即時的 DIC は認められず，後者の合併としてはアナフィラキシーの如き機序を考慮する必要があると 考觉られた。
\end{abstract}

\section{緒}

言

局所用トロンビン製剤は出血部位に直接噴霧または散 布して局所の凝固を促進せしめる局所止血剤で，皮膚剥 離面, 藏器損傷, 潰瘍あるいは手術創などの出血に有効 な止血剤として繁用されてきた．しかるに最近極めて稀 ではあるが, 肝穿刺出血部位に散布すると即時的なショ ック症状, 次いで DIC 様凝固異常が現れた例, また胃 潰瘍の出血に対し服用を続けているとアレルギー様症状 が現れた例が報告された.

実験的にトロンビンを静脈内注射すると主として肺循

* 昰199-01 神奈川県津久井郡相模湖町寸沢嵐1091-1

** 昰173 東京都板橋区加賀2-11-1
環系に血栓を多発してショック様症状を来たし, 同時に 血小板減少や，凝固因子の低下を来たして烈しいDIC 様所見が現れる1). したがって, 上記の例に打ける患者 の反応としては局所的に使用されたトロンビンが血流中 に大量に侵入してこのような烈しい反応を惹起する機序 が考觉られる.

さらに肝疾患ことに慢性肝炎, 肝硬変などでは血小 板, 凝固因子, 凝固・線溶系インヒビターなどが減少し て, 凝固系のホメオステーシス維持機能が低下してお $\eta^{2)}$ ，またこれらの疾患患者はいわゆる潜在性 DIC 状

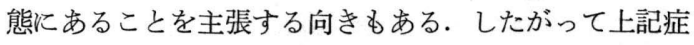
例のような場合, 少量のトロンビンが血流に侵入して 子容易に DIC 状態を来すといら可能性を否定出来な (3). 
本研究ではこれらの機転を明らかにすべくラットに実 験的に諸種の肝障害を作成し，トロンビンをその腹腔内 に注射した場合の凝血学的変化を追跡すると共に, 諸臓 器の組織学的検索を行なった.

\section{実験材料および実験方法}

\section{材 料}

1.トロンビン製剤：局所止血剂として用いられる 「局所用トロンビン」(Parke Davis) 5, 000 単位 (U)/ vial を，用時生食に溶解して使用した。 またこの製剤 から塩析およびクロマトグラフィー法などによりトロン ビンを除去した「トロンビン除去蛋白」の凍結乾燥分画 は自治医大血液研松田道生氏により作成供与された。本 実験ではトロンビン製剤 1 単位から得た本分画量を「ト ロンビン相当量 1 単位」と表現した.

2. 実験動物: 肝硬変ラットはウィスター系雄性ラッ 卜（体重約 $200 \mathrm{~g}$ ) 飞四塩化炭素 $(0.12 \mathrm{ml} /$ ラット) を 週 2 回腹腔内に注射し，12週間続けることで作成した. 急性肝障害ラットとしては四塩化炭素 $(0.15 \mathrm{ml} / 100 \mathrm{~g}$ 体重）の腹腔内注射後 24 時間の群および48時間目の群を 用いた. 本研究で作成したラットの肝硬変モデルは死 後, 開腹し肝臓を剖検すると硬化, 白色化し, 組織学的 には不規則な肝小葉結節の形成および結節間の巾広い結 合組織增殖, 散在性の脂肪変性が認められて, 肝硬変像 が明らかであった。

\section{方 法}

1.トロンビンの腹腔内注射実験 : 「局所用トロンビ ン」 $500 \mathrm{U} / \mathrm{ml}$ 液を $10 \sim 1,000 \mathrm{U} / 100 \mathrm{~g}$ 体重の量で, 対 照未処置群 $(n=20)$, 肝硬変群 $(n=20)$ および急性肝 障害群 $(\mathrm{n}=20$ および 28$)$ の腹腔内注射し,「トロン ビン除去蛋白分画」は体重 $100 \mathrm{~g}$ 当り900単位トロン ビン相当量 (900単位トロンビン製剤より得られた分画 全量）を急性肝障害 48 時間群 $(n=20)$ 飞腹腔内注射乙 た.

トロンビン製剤をたは「トロンビン除去蛋白分画」を 投与後， $5 ， 10,30,90$ 分の時点で各々 5 匹 1 群として エーテル麻酔下に開胸し，心採血した. 血液は $3.8 \%$ ク エン酸ナトリウムの $1 / 10$ 容と混和しクェン酸加血として 採取した. クェン酸加血は室温で $800 \mathrm{rpm} 15$ 分間の遠 心炕より多血小板血漿 (PRP) を，3,000 rpm 15分間の 遠心によりクェン酸加血漿を得た。

2. 血小板数算定 : 血小板数は自動血小板計数装置 (Sysmex Platelet Counter PL-100, 東亜医用電子株 式会社, 東京)を用い, PRP を希釈し計測した。
3.フィブリノーゲン量：フィブリノーゲン量は フィブリノーダン測定用キット Fibrinogen Test ${ }^{\circledR}$ (Boehringer Mannheim)を用い，クエン酸加血漿を 希釈後, 一定量のトロンビンを添加し，凝固時間を測定 することにより求めた.

4. PT および APTT : プロトロンビン時間 (PT) は Thromborel ${ }^{\circledR}$ (Behring Institute) $)^{4}$, 活性化部 分トロンボプラスチン時間 (APTT) は Pathromtin ${ }^{\circledR}$ (Behring Institute) を用いて測定した5).

5.トランスアミナーゼ活性の測定：血墏トランスア ミナーゼ活性はその測定用キット（S. TA-Test Wako, 和光純薬株式会社，大阪）を用い， Reitman-Frankel 法の変法6りより測定した．活性はカルメン単位で表わ した.

6. アンチトロンビン III（AT-III）活性の測定：ク エン酸加血漿を検体としてテストチームAT-III キッ $卜$ (第 1 化学)を用いた. すなわち稀釈検体に，へパ リン入り緩衝液, 一定量のトロンビンを順次加え, 検体 中に形成されたヘパリン・AT-III 複合体で失活されな かった余剩のトロンビン活性を, 発色合成基質 $(\mathrm{H} \cdot \mathrm{D}$ フェニルアラニル-L-ピペコリルーL-アルギニン-P-ニ トロアニリド）の水解量を求めることにより定量した.

7. 組織学的所見: 実験中各時点で各々 5 匹 1 群とし て心採血したラットは, 直ちに屠殺して, 肺・心・腎・ 肝をフォルマリン固定し, 組織学的検索を行なった.

\section{実 験 結 果}

1. トロンビン腹腔内注射による肝硬変ラットの凝血学 的経時变化

肝硬変群と末処置対照群へトロンビン製剂 $100 \mathrm{U} /$ $100 \mathrm{~g}$ 体重を腹腔内投与した際の血液凝固パラメーター に及ぼす影響を検討した．肝硬変のラットではトロンビ ン投与前既に血小板数は, 対照群の 2 倍に增加していた $(\mathrm{P}<0.01)$ が, フィブリノーゲン量, PT および APTT は両群の間で差が見られなかった（図1).

未処置対照群にトロンビンを注射すると，5および 90 分後に血小板数は有意の上昇 $(\mathrm{P}<0.01)$ を示したが, 肝硬変ラットヘトロンビンを投与して90分まで追跡して も，血小板数は有意の変動を示さなかった（図 1-a). 一方フィブリノーゲン量, PT および APTT 值は両群 とも投与前值と比べて有意な変動は認められなかった (図 $1-b \sim d$ ). 血中 GPT 活性は肝硬変群ではすでに 高值を示しており，トロンビンの投与 90 分後で，血中 GPT 活性はさらに上昇した（図1-e ）. 


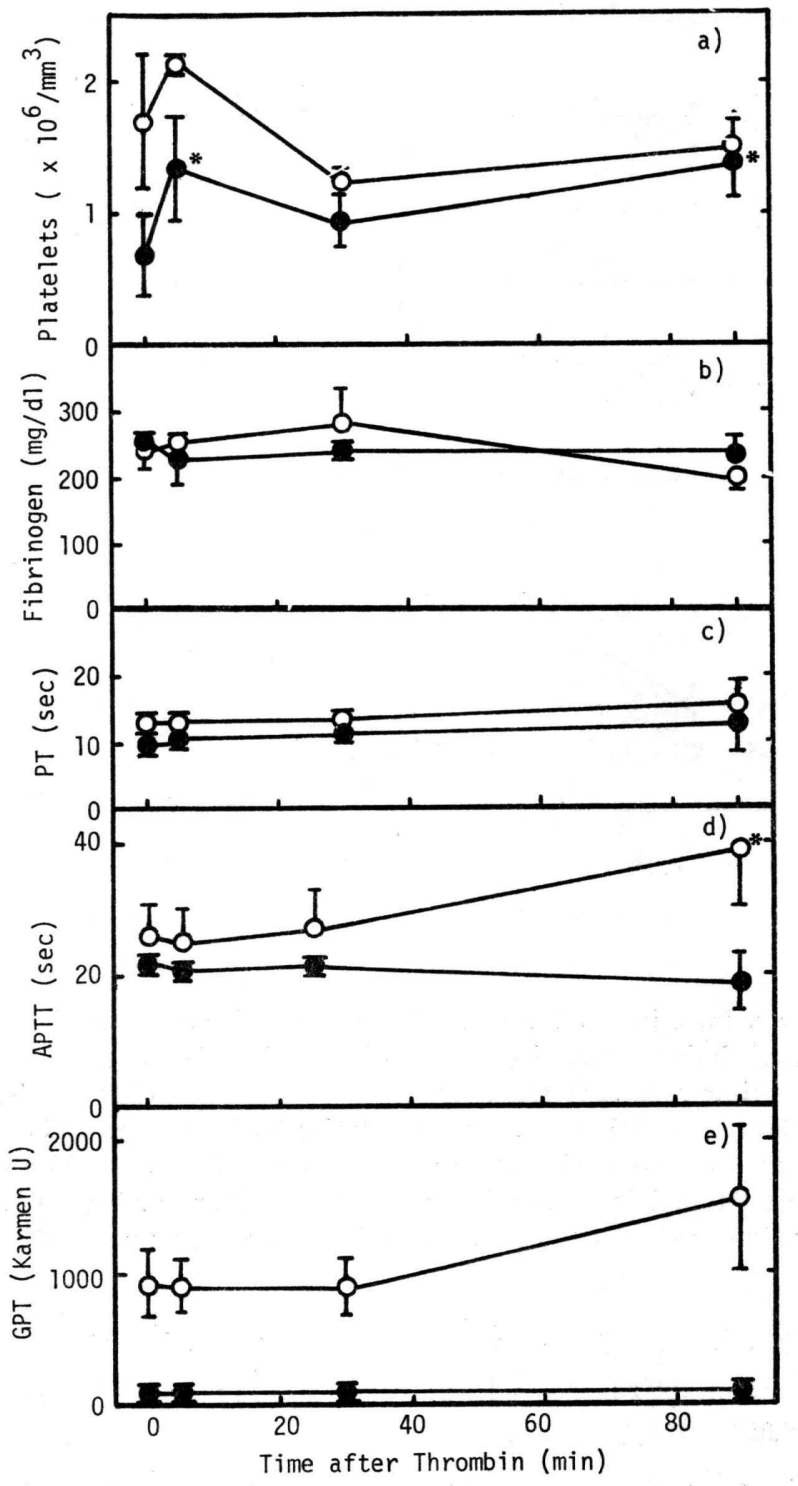

* $\mathrm{p}<0.01$

Fig. 1 Effect of i.p. injection of thrombin ( $100 \mathrm{U} / 100 \mathrm{~g}$, b.w.) on the blood clotting factors of rats with $\mathrm{CCl}_{4}$-induced liver cirrhosis. Each group consisted of 5 animals and points represent the mean \pm S.D. The open circles indicate values of the rats with $\mathrm{GCl}_{4}$-induced liver cirrhosis and the closed circles indicate those of the untreated control. a) Platelet count in the platelet rich plasma, b) Fibrinogen content, c) PT, d) APTT, e) Serum GPT activity. Asterisk indicates the significant difference $(\mathrm{P}<0.01)$ between the value prior to thrombin injection and those at 5 and $90 \mathrm{~min}$.

2. トロンビン腹腔内注射による急性肝障害ラットの凝 血学的経時変化

トロンビン製剤の腹腔内注射が急性肝障害ラットの血
液凝固系に及ぽす影響を検討するために，四塩化炭素投 与後24時間と48時間のラットを用いた.

四塩化炭素投与 24 時間後のラットの血小板数は未処 


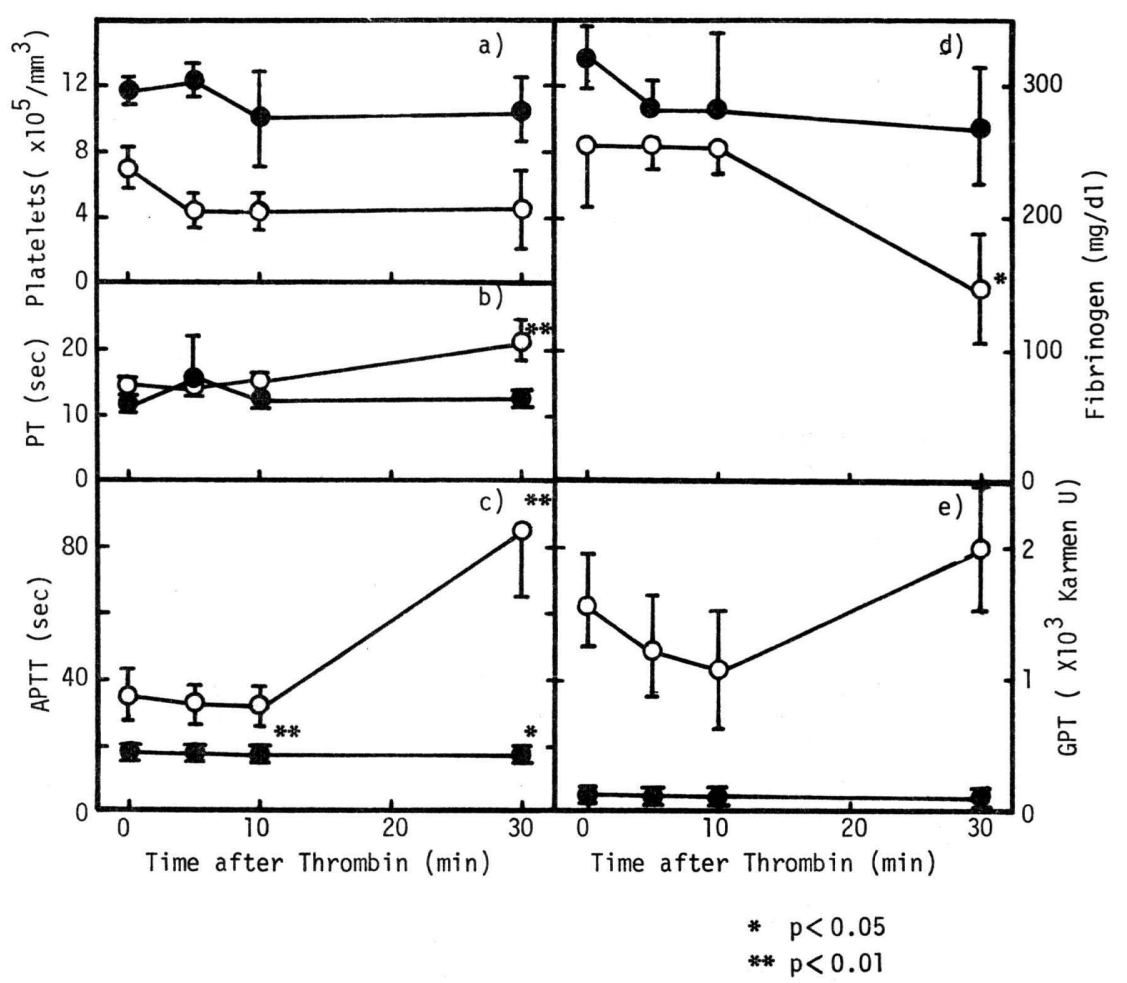

Fig. 2 Effect of i.p. injection of thrombin (100 U/100 g, b.w.) on the blood clotting factors of rats with the $\mathrm{CCl}_{4}$-induced hepatitis ( $48 \mathrm{hr}$ after $\mathrm{CCl}_{4}$ injection). Each group consisted of 7 animals and points represent the mean \pm S.D. The open circles indicate values of the rats with $\mathrm{CCl}_{4}$-induced hepatitis and the closed circles indicate those of the untreated control. a) Platelet count in the platelet-rich plasma, b) PT, c) APTT, d) Fibrinogen content in plasma, e) Serum GPT activity. Asterisks indicate significant differences between the value prior to thrombin injection and those at the different times in the experiment.

置対照群よりも $30 \%(\mathrm{P}<0.01)$, フィブリノーゲン量は $35 \%(\mathrm{P}<0.01)$ 減少し, $\mathrm{PT}$ と APTT は各々 1.9 倍 $(\mathrm{P}<0.01)$ と 1.8 倍 $(\mathrm{P}<0.05)$ に延長していた. しか 乙, $100 \mathrm{U} / 100 \mathrm{~g}$ 体重のトロンビン製剤を投与しても, それらパラメーター值は肝障害群でも未処置対照群でも 変動が全く認められなかった (Data 省略).

四塩化炭素投与後48時間の肝障害ラットでは血小板数 は未処置対照群よりも $40 \%$ 減少し $(\mathrm{P}<0.01), \mathrm{PT}$ およ び APTT は各々 1.2 倍 $(\mathrm{P}<0.05)$ と 1.9 倍 $(\mathrm{P}<0.01)$ に延長していた.フィブリノーゲン量は有意な差はなか った（図 2 ).この群にトロンビン $100 \mathrm{U} / 100 \mathrm{~g}$ 体重を 注射すると, 血小板数とフィブリノーダン量は減少する 傾向を, PT 拉よび APTT は延長する傾向を示した. 特に, トロンビン投与後30分では投与前值よりも血小 板数が $30 \%$ (有意差なし), フィブリノーゲン量が $45 \%$
減少し $(\mathrm{P}<0.05), \mathrm{PT}$ 扰よび APTTは各々 1.5倍 $(\mathrm{P}<0.01)$ と 2.3 倍 $(\mathrm{P}<0.01)$ に延長した（図2-a〜 d).

このPT および APTT 延長の原因をみるために, 四塩化炭素投与の 48 時間後の群にトロンビン製剤を投与 して明らかな凝固異常を認めた 30 分後の血墏に，1/4 量 の対照血墏を加えると, PT は完全に対照と同じ値に回 復し, APTT も著しく改善された（図 3 ). このこと は, この PT 和よび APTT の延長は凝固因子の欠除 によって生じたものであることを示している.

肝障害ラットの血中 GPT 活性はトロンビン製剤投 与30分後に上昇の傾向が見られた（図2-e ）.

未処置対照群へのトロンビン投与は血液凝固系にも GPT 值にもまったく影響を怙よぼさなかった。 


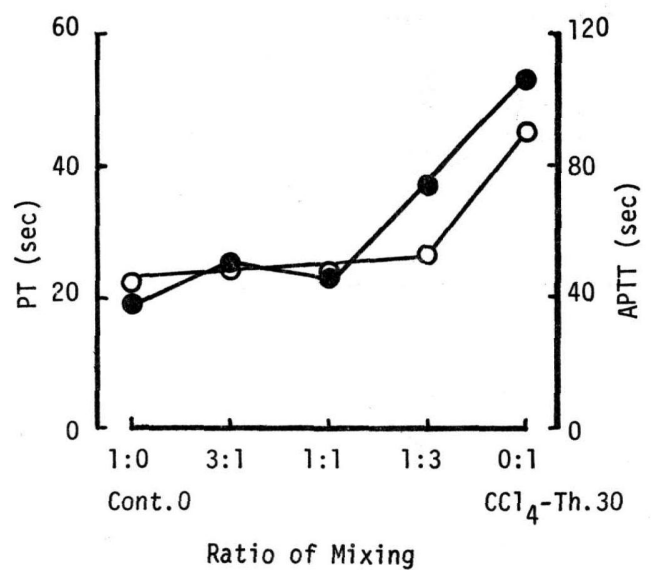

Fig. 3 Correction of prolonged PT and APTT of the plasmas of rats with $\mathrm{CCl}_{4}$-induced hepatitis $\left(48 \mathrm{hr}\right.$ after $\mathrm{CCl}_{4}$ injection) and injected with thrombin by addition of the control plasma. The open circles indicate the values of PT, and the closed circles indicate the values of APTT. Cont. 0 indicates the plasma of the control rats. $\mathrm{CCl}_{4}$-Th. 30 indicates the plasmas collected $30 \mathrm{~min}$ after thrombin treatment from the rats with $\mathrm{CCl}_{4}$-induced hepatitis.

\section{3. 急性肝障害ラットにトロンビン腹腔内注射した際の} 凝血学的変化のトロンビン用量依存性

四塩化炭素投与48時間群へトロンビン製剤を投与する と, 凝血学的変化が認めら机たことから, この変化の トロンビン用量体存性を検討した.すなわち急性肝障 害の 48 時間群にトロンビン 20,100 あるいは $1,000 \mathrm{U} /$ $100 \mathrm{~g}$ 体重を腹腔内注射し, 30 分後に採血して凝血学的 検査を行なった.

トロンビン $20 \mathrm{U} / 100 \mathrm{~g}$ 体重を腹腔内に注射しても血 小板数, フィブリノーゲン量, PT および APTT は対 照の非投与群と同じ値であった（図 4 ）. しかし，100 $\mathrm{U} / 100 \mathrm{~g}$ あるいは $1,000 \mathrm{U} / 100 \mathrm{~g}$ を注射すると明らか な変化が現われ，ことに PT と APTT の延長は著し く, トロンビン $1,000 \mathrm{U} / 100 \mathrm{~g}$ 注射群ではトロンビン 非投与対照群に比べ各々 2.5 倍と 1.8 倍に延長した（図 4-a 〜 d). AT-III は肝障害ラットに扮いてすで著 しく低下しており，未処置対照群の $25 \%$ であったが，肝 障害ラットにトロンビンを投与しても，AT-III の值が さらに変化することはなかった（図4-f）.

肝障害ラットで著しく上昇していたトランスアミナー ゼ活性はトロンビン製剤の用量依存的に上昇した（図 $4-\mathrm{e}$ ).
4.「非トロンビン蛋白分画」の腹腔内注射による急性 肝障害ラットの凝血学的変化

900 U のトロンビン製剤から分離した「非トロンビン 蛋白分画」一匹当り 900 トロンビン単位相当量を, 四塩 化炭素投与後48時間のラットに投与し, 凝固系におよぼ す影響を検討した（図 5 ).

肝障害ラットの APTT はこの分画投与後 30 分で約 1. 5 倍に延長した $(P<0.05$, 図 5 c $)$ が, 血小板数, フィブリノーゲン量就よ゙ PT には変動が認められな かった (図 5-a〜d).

肝障害ラットの血中 GPT 活性は本分画投与により 約 2 倍に上昇した（図 5-e ).

\section{5. 組織学的所見}

四塩化炭素投与 24 時間ラットの肝は小葉中心性に肝細 胞の腫脹, 壊死が見られ, 壊死部への軽度の細胞漫潤が 認められたが脂肪変性は認められなかった（写真 1 ). 四塩化炭素投与週 2 回, 12 週反復後ラットの肝は肉眼的 に表面に顆粒状の結節形成を認め, 組織学的には肝細胞 の多様性小葉結節が不規則に形成され, 結節間には巾広 い結合組織の増殖, 散在性の脂肪変化が認められて, 肝 硬変像が明らかであった（写真 2 ).

四塩化炭素48時間ラットの肝でも, 小葉中心性の肝細 胞の腫脹, 壊死および壊死部への細胞浸潤など写真 1 と ほぼ同様の所見が得られたが (写真 3 ), 肺 (写真4) および腎 (写真 5 ) には特に病変所見を認めなかった。

この群にトロンビン $1,000 \mathrm{U} / 100 \mathrm{~g}$ 体重を注射し, 30 分後に屠殺したラットの組織学的検索を行なった、肝 はトロンビン注射前とほぼ同様の急性肝障害の所見を示 したのみで, 本藏器 (写真 6 ), 肺 (写真 7) および腎 (写真 8 ) の何れの血管にも血栓は認められなかった.

四塩化炭素投与48時間群にトロンビンの代りに「非ト ロンビン蛋白分画」を注射した場合でも, 肝は急性肝障 害の像を示すのみで (写真 9 ), その他肺 (写真10) お よび腎（写真11）の何れの血管にも血栓は認められなか った

\section{考察}

本研究の目的は, 組織面よりのトロンビン吸収-DIC 発現の可能性を実験的に追跡することにある. 問題の出 発点であった肝硬変患者へのトロンビン製剤局所使用時 に発現した烈しい反応は, トロンビン使用後極めて短時 間で現われている. そこで本研究では, トロンビン製剤 投与後 90 分以内の短時間内での凝血学的パラメーター特 よびバイタルサインの変化（例㓪ば行動, 姿勢, 呼吸の 


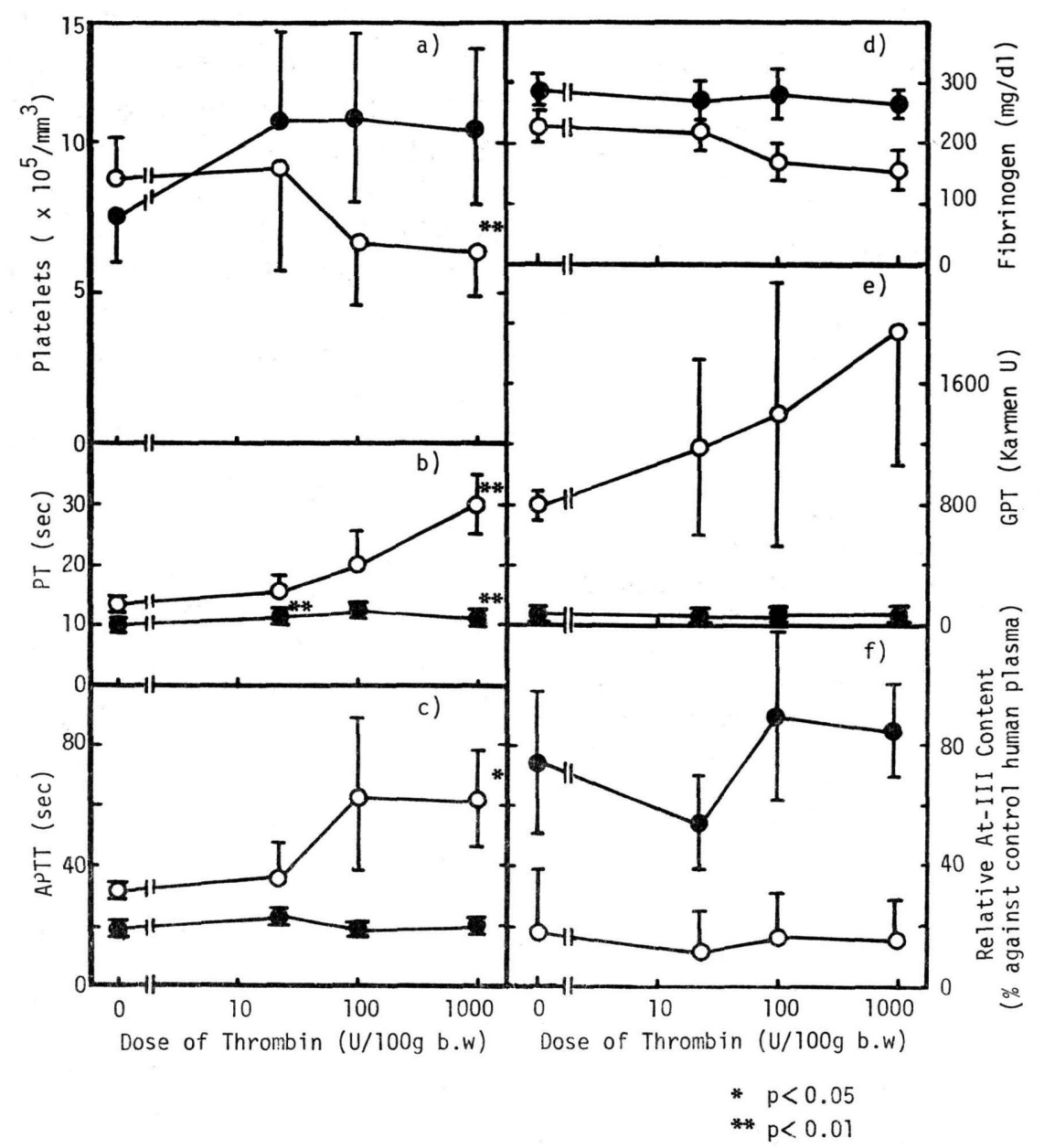

Fig. 4 Effect of thrombin dosage, i.p. injection, on the blood clotting factors of rats with $\mathrm{CCl}_{4}$-induced hepatitis ( $48 \mathrm{hr}$ after $\mathrm{CGl}_{4}$ injection). Each group consisted of 5 animals, and the points represent mean \pm S.D. The open circles indicate values of the rats with $\mathrm{CCl}_{4}$-induced hepatitis, and the closed circles indicate those of the control. a) Platelet count in platelet-rich plasma, b) PT, c) APTT, d) Fibrinogen content, e) Serum GPT activity, f) AT-III content in plasma. Asterisks indicate significant differences between the values of the controls not injected with thrombin and those of the groups injected with different dosages of thrombin.

異常および立毛, 下痢, 出血, チアノーゼなどの異常所 見)を観察することを目的とした. トロンビン製剤 100 $\mathrm{U} / 100 \mathrm{~g}$ 体重の投与量は臨床的使用量の約10倍に当る. この投与量では, トロンビン製剤投与後, 肝硬変群和よ び対照群ともにバイタルサインの異常は認められず,さ らに凝血学的パラメーターにもトロンビン製剤の影響は まったく認められなかった。

一方, 四塩化炭素により急性肝障害を起させたラット の中, 四塩化炭素投与24時間後の群ではトロンビンを投
与しても㠜血学的変化は認められなかったが, 四塩化炭 素投与48時間後の群ではトロンビン投与30分後で血小板 数減少, APTT 延長, フィブリノーゲン減少などの所 見が得られた. またこの凝血学的変化にはトロンビン用 量依存性が認められた. しかし $1,000 \mathrm{U} / 100 \mathrm{~g}$ といら投 与量は臨床的使用量の 100 倍に相当するのにショック症 状は認められなかった. この四塩化炭素投与48時間後の ラットの $60 \%$ に著明な腹水の貯留が認められた. 腹水が 貯留するような場合, 腹膜を介しての血管と腹水の間で 


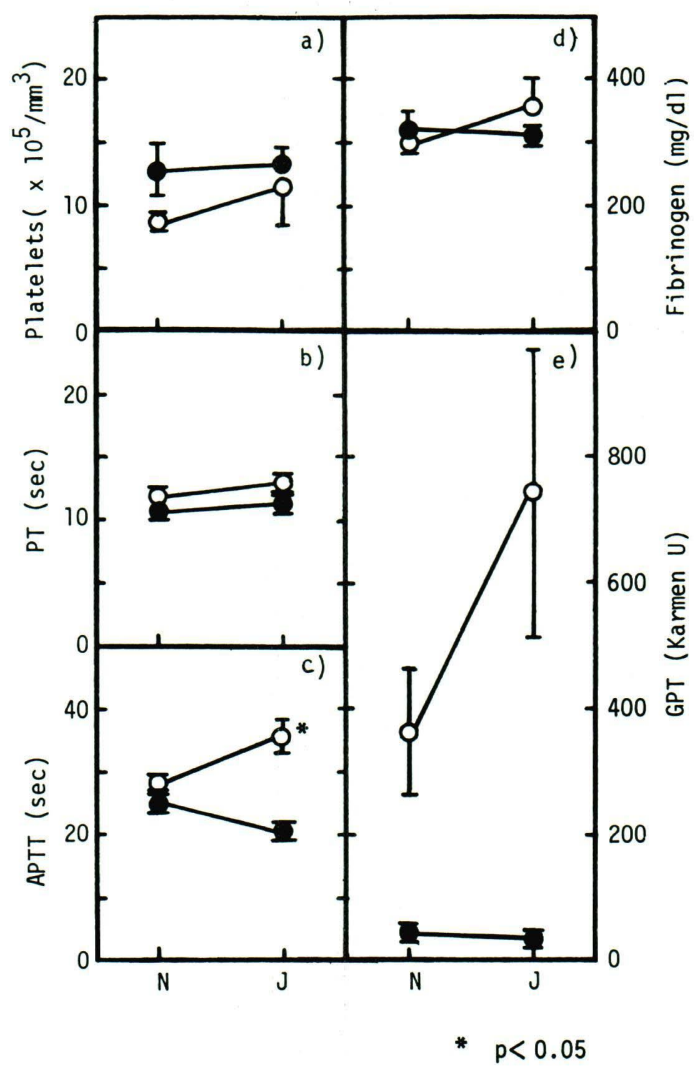

Fig. 5 Effect of injection of the "Junk" fraction on the blood clotting factors of rats with $\mathrm{CCl}_{4}$ induced hepatitis ( $48 \mathrm{hr}$ after $\mathrm{CCl}_{4}$ injection). The " $\mathrm{J}$ " indicates rats injected with the "Junk" preparation and the " $\mathrm{N}$ " indicates the controls injected with saline. The amount of "Junk" injected per $100 \mathrm{~g}$, b.w. corresponded to 900 units of thrombin preparation, from which the "Junk" was prepared. Each group consisted of 5 animals and points represent the mean \pm S.D. The open circles indicate values of the rats with $\mathrm{CCl}_{4}$ induced hepatitis, and the closed circles indicate those of the control. a) Platelet count in plateletrich plasma, b) PT, c) APTT, d) Fibrinogen content, e) Serum GPT activity. Asterisk indicates the significant difference $(\mathrm{P}<0.05)$ of APTT between the control group (N) and the one injected with "Junk" preparation (J) of rats pretreated with $\mathrm{CCl}_{4}$.

電解質のみならず諸物質の動員に異常があることも想定 され，物質交換が血管と組織の間で起りやすい時には, 腹腔内に投与したトロンビンも対照群に比べ吸収されや すいと考えられる. しかし，ヒトで認められたトロンビ
ン製剤噴舅による副作用に比べ，本実験で認められた凝 血学的異常は, トロンビン投与後30分で始めて認められ たこと, 投与量は臨床での使用量の約10倍であったこと から考え, 単に月下障害時トロンビンの吸収が増した事の みにより圳時的なショックがもたらされる状況は推定さ れない.

AT-III は川障害時, 著減することは知られてお $り^{7)}$, 図4-f の結果と一致する. H障害ラットへのトロ ンビンの投与で, AT-III 值がさらに低下することはな かった．これは急性肝障害ラットへのトロンビン腹腔内 投与により，これが血管内に吸収されたとしても，ATIII の消費を来すほどのものではなかったことを示唆し ている.

局所用トロンビン製剤は完全な精製物ではなく，混在 蛋白を含む血漿分画製剤である. 本製剤によって発生し たとされる副作用が，この混在物質によるものか否かを 検討した. 本実験に用いられたトロンビン製剤から松田 らにより作成された「トロンビン除去蛋白」部分を濃縮 し, トロンビン 900 単位相当量を肝障害ラットに投与し たが凝血学的変化は APTT の軽度延長以外には認めら れなかった. この際フィブリノーゲン減少が認められな かったことは, APTT に関与する他因子すなわちXII, XI, X, X, VIII, V, IIの何れかが減少したことを示唆 する. しかし本分画中には血流中での凝固因子活性化ひ いては消耗を来たすような活性型因子は検出されず，こ の APTT 軽度延長の理由は不明である.トロンビン製 剤 $100 \sim 1,000 \mathrm{U} / 100 \mathrm{~g}$ 体重量の腹腔内注射で認められ た著明な凝固異常は主としてトロンビンそのものによる ことを示唆している.

本トロンビン製剤を肝硬変および急性肝障害ラットに 投与すると，血中 GPT 活性はその投与量に比例して 著しく上昇した.このことはトロンビン製剤を肝障害時 に局所的に適用すると肝機能障害を進行させる可能性の あることが考えられ，その原因物質は本製剤の非トロン ビン蛋白分画部分にもあることが示唆された.

以上の様な凝血学的所見は確かに汎発性血管内凝固症 候群に準ずるものである. 臨床的には微小血栓多発によ る臟器機能不全が重要症状の一つとなるが，本実験では トロンビン注によっても，「非トロンビン蛋白分画」に よっても肝はもとより, 微小血栓の発見され易い肺ある いは腎系球体にも血栓は全く認められなかった.この際 のトロンビン投与量はヒトに換算して 60〜70万単位に相 当する. 種差を考虑に入れねばならぬものの, トロンビ ン腹腔内注入が臓器障害を来たす程の微小血栓形成を直 

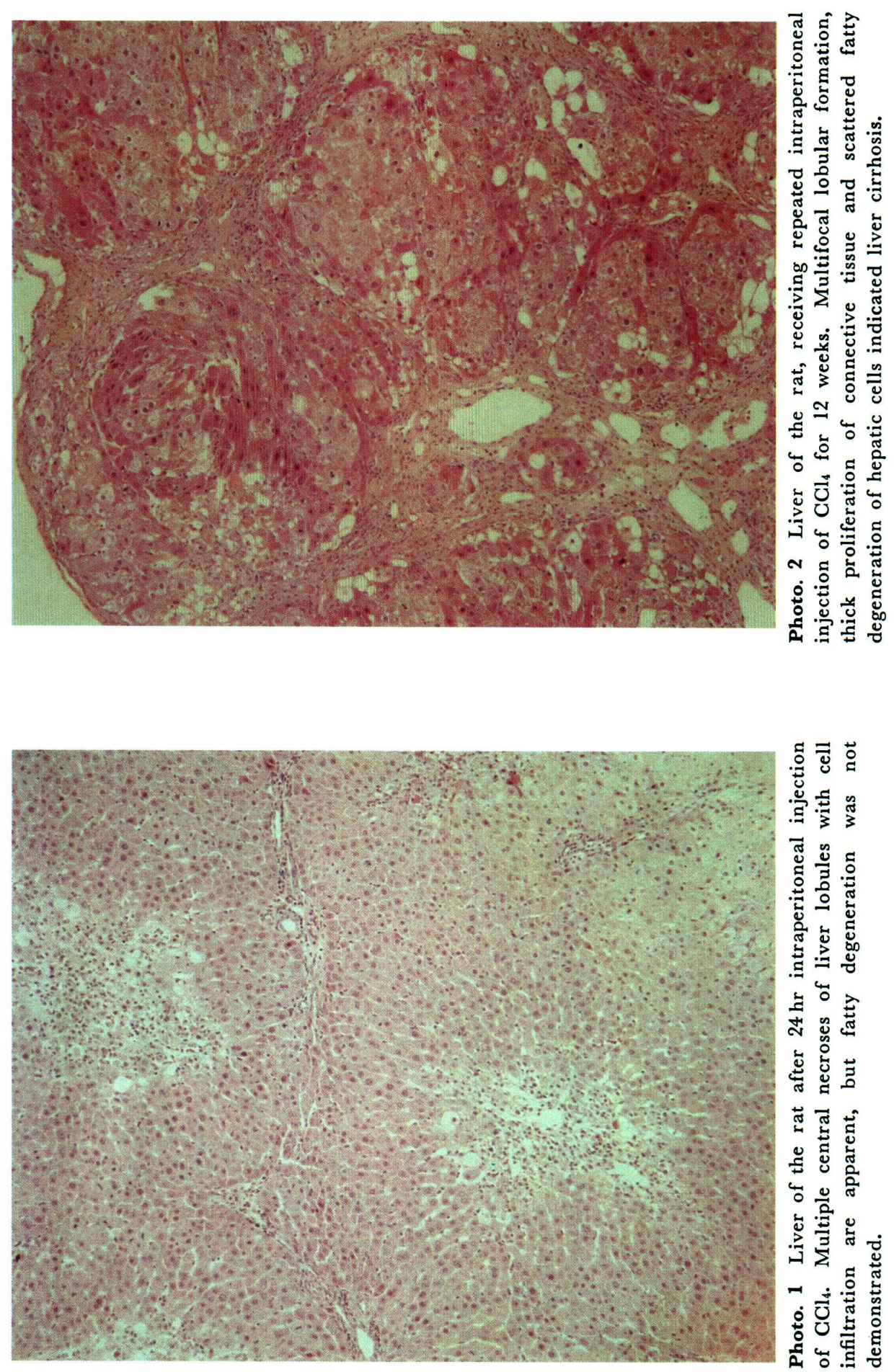

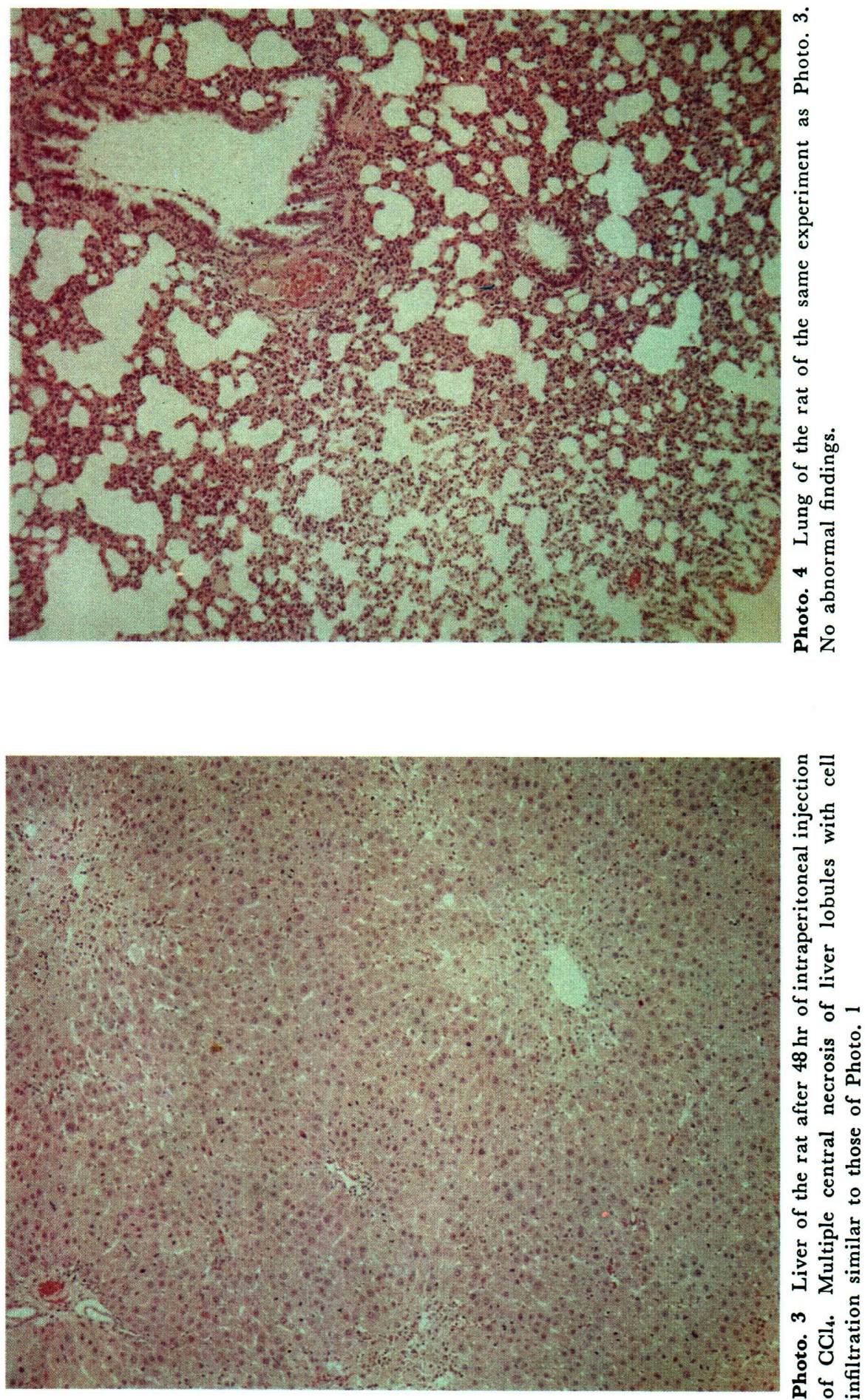


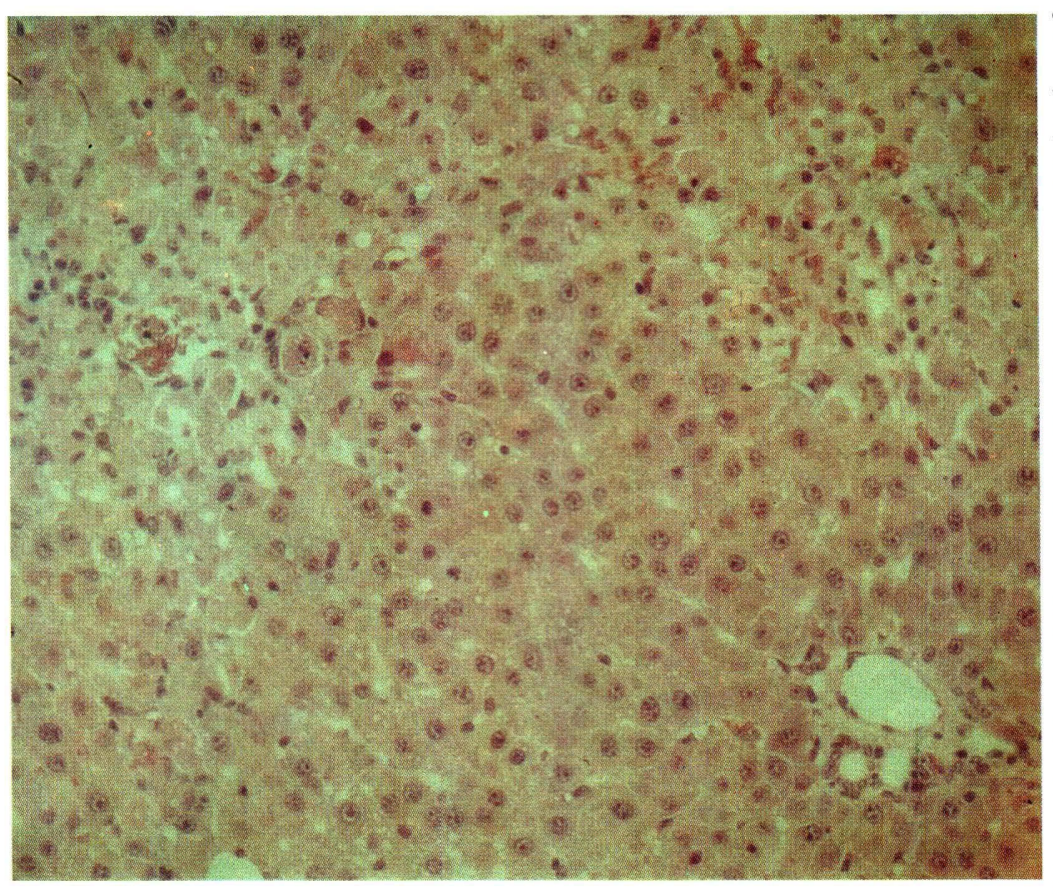

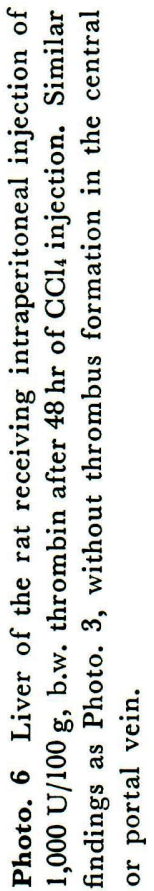
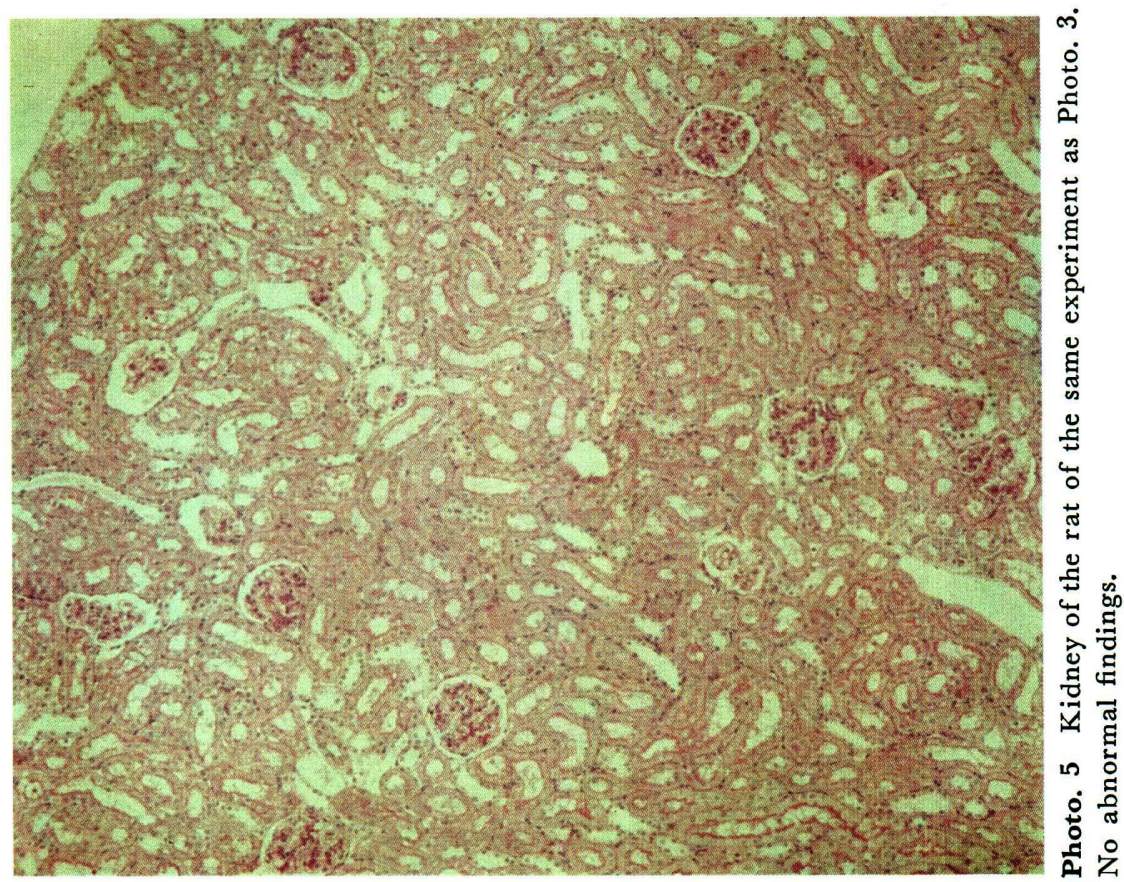

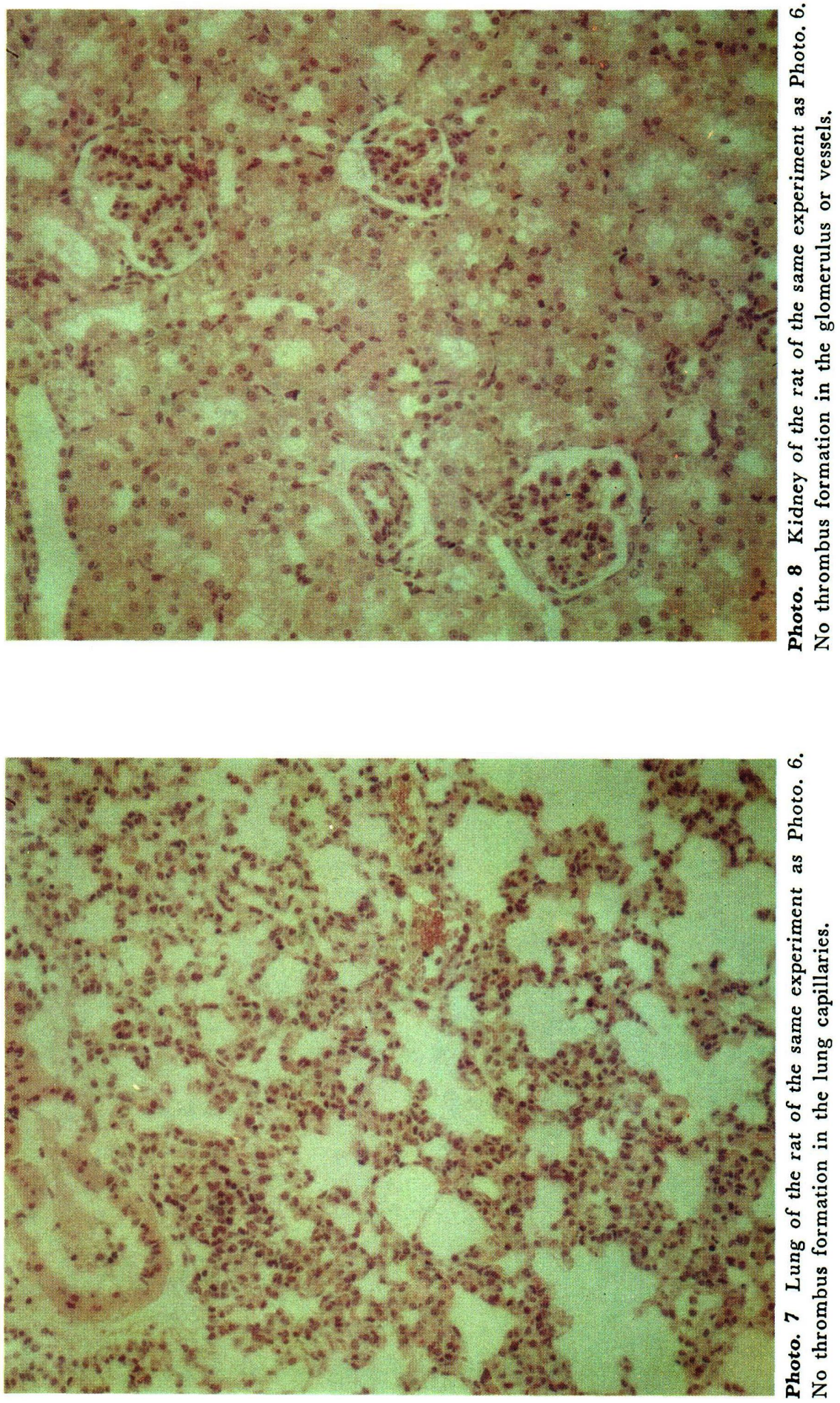

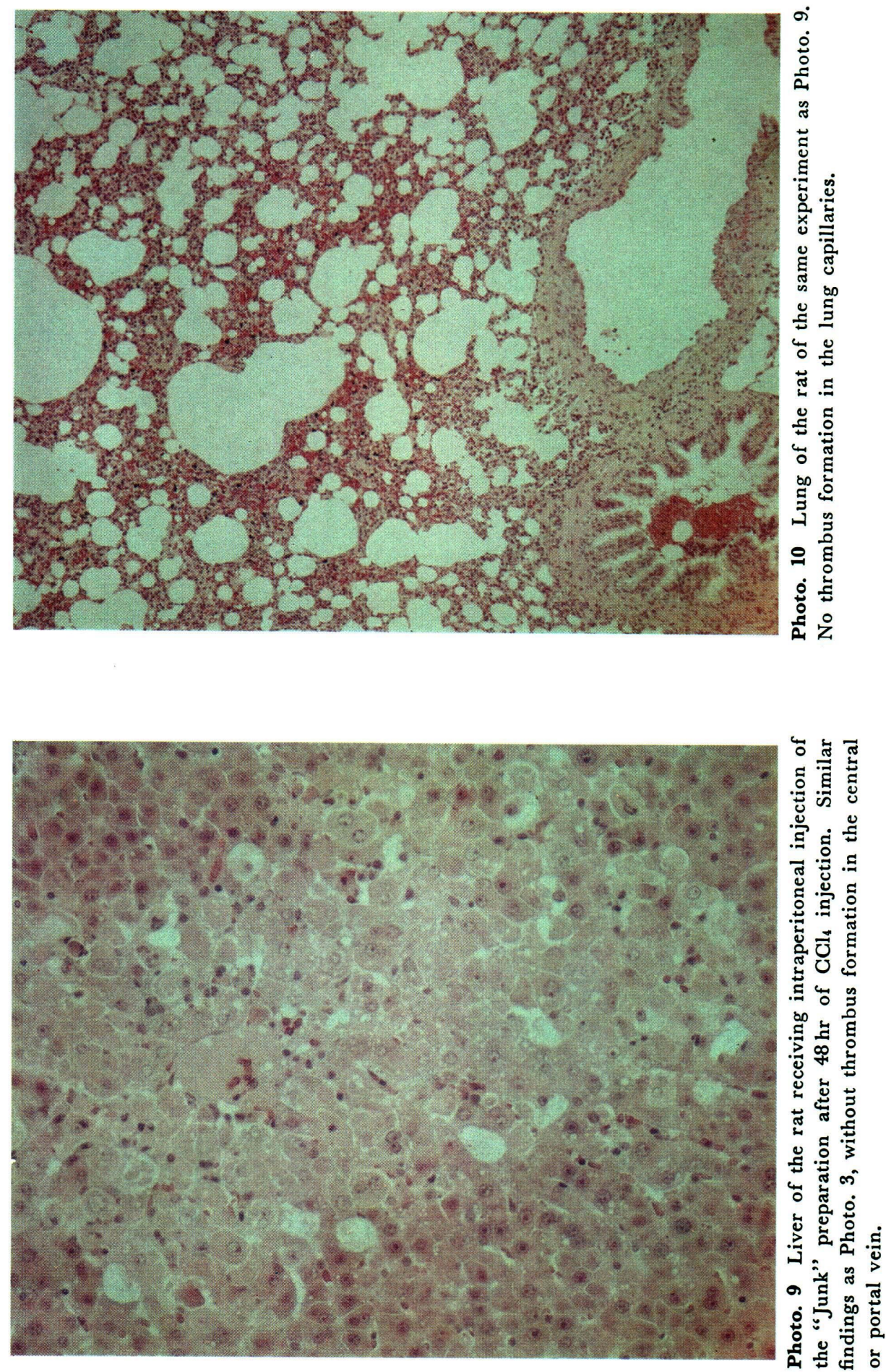


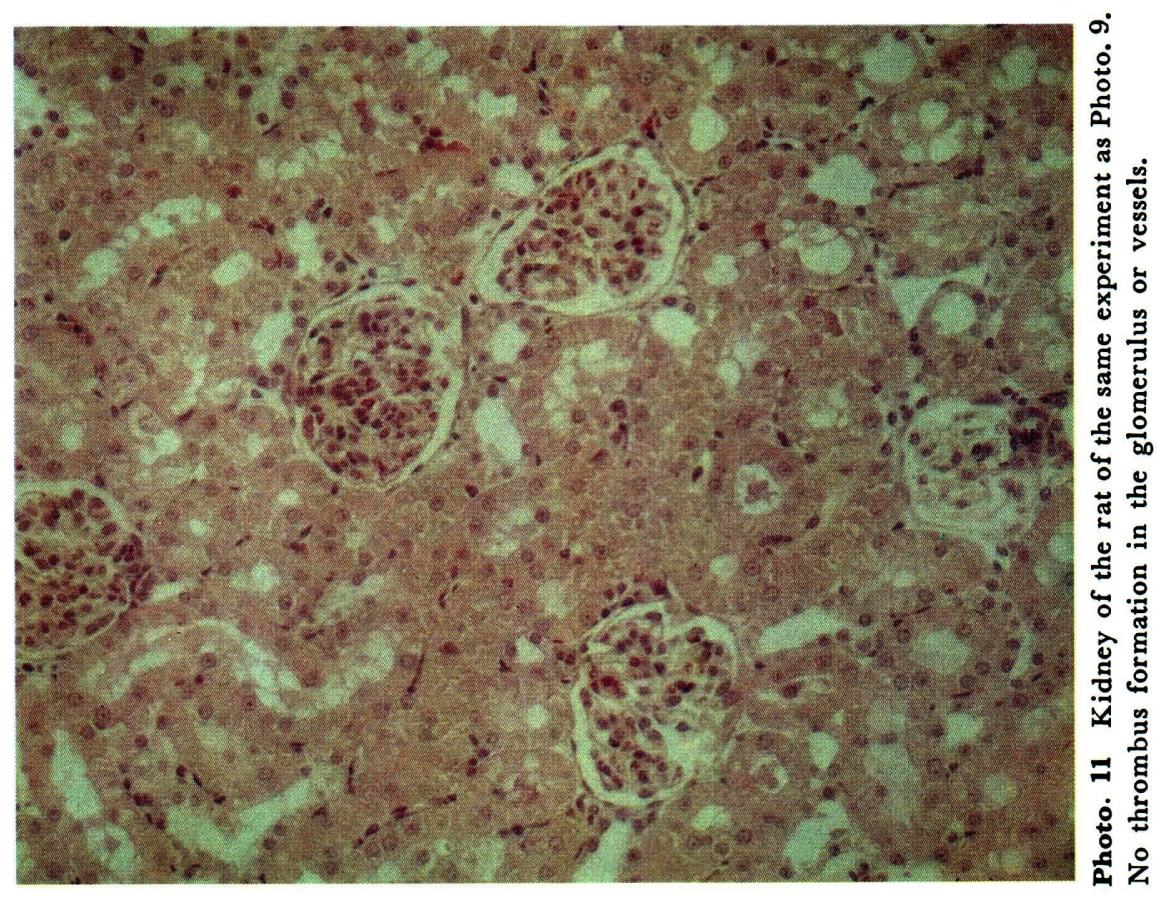


接惹起する可能性は極めて少ない.

臨床的にトロンビン製剂の局所的使用時に極めて稀で はあるが報告されるショックや DIC 発現の機序につ き, 本研究の成績から考察してみたい, 本研究では腹水 を伴う程の急性肝障害ラットに大量のトロンビンを腹腔 内に注射した時にの久 DIC 様の凝血学的異常が現われ た.この機転としては腹腔の蛋白透過性元進によってト ロンビンの末梢血中へ侵入が増大していた為か，あるい はトロンビンの侵入の程度は大きくはないが，肝障害の 芯め凝血系の平衡維持能が減弱していた為などが考兄ら れる. したがって臨床的にも腹水貯留を伴う程の肝障害 患者に対してはトロンビン製剤の局所的使用は慎重に行 らべきであろう。

しかし，報告されているようなトロンビン局所使用直 後から現われる烈しいショック状態, 続いて DICの発 現は本実験では認められず，DIC 類似の凝固異常も卜 ロンビン腹腔内注入後 30 分にして始めて明らかになる程 度のものであった．実験的には大量のトロンビンを急速 に血管内に注射した場合にのみこのような烈しい反応が 現われる.
したがって臨休的に見られる如き烈しい反応は血管外 に局所的に使用したトロンビンの凝固作用によるとは推 定し得ず，むしろトロンビン製剤に対するアナフィラキ シーの如き機序を考えるべきではないかと結論された.

謝辞 : 本研究を行うに当り終始御指導を下された本学 安部 英医学部長に感謝します。

\section{文献}

1) Jastebski, I., Arnot, R.N., Hilgard, P. and Sykes, K.: Br. J. Anesth. 47, 654 (1975)

2) 山本祐夫, 吉村良之介: 医学の歩久 109, 97 (1975)

3) Tytgat, G.N., Collen, D. and Verstraede, M.: J. Clin. Invest. 50, 1690 (1971)

4) Quick, A.J.: Hemorrhagic Diseases, 1st., Lea and Febiger, Philadelphia (1957)

5) Rodman, N.F., Barrow, E.M. and Graham, J.B.: Am. J. Clin. Pathol. 29, 525 (1958)

6) Schaffert, R.R., Kringsley, G.K. and Getchell, G.: Clin. Chem. 8, 429 (1962)

7) Duckert, F.: Scand. J. Gastroenterol. 8, Supp. 19,109 (1973)

\begin{abstract}
Hidemi ISHII, Masaaki KUBOKI, Minoru OHKURA, Sayuri HIRAISHI, Jiro TSUBOUCHI and Mutsuyoshi KAZAMA* (Clinical Biochemistry, Department of Pharmaceutical Sciences, Teikyo University, 1091-1, Suarashi, Sagamiko-machi, Tsukui-gun, Kanagawa 199-01, Japan and *Department of Internal Medicine, Teikyo University School of Medicine, 11-1, Kaga 2 chome, Itabashi-ku, Tokyo 173, Japan). Effect of intraperitoneal injection of topical thrombin on the coagulation and fibrinolysis of rabbits with experimental liver damages. Folia pharmacol. japon. 85, 97 110 (1985)

Topically applied thrombin was known to be effective in hemostasis of local bleeding, but complications of shock, anaphylaxis or disseminated intravascular coagulation (DIC) have been reported recently in rare cases. In this experiment, the possibility of DIC was examined by intraperitoneal injection of topical thrombin (Parke-Davis) to rabbits with liver cirrhosis or acute liver damages induced by $\mathrm{CCl}_{4}$. No significant changes in the coagulation parameters were found in the groups of liver cirrhosis or the untreated control, but the injection of thrombin induced decreases of platelet count and fibrinogen and prolongation of prothrombin time and partial thromboplastin time in the groups of acute liver damages, 24 or $48 \mathrm{hr}$ after $\mathrm{CCl}_{4}$ injection. When the "junk" prepared from the topical thrombin was injected to the $48 \mathrm{hr}$-damage group, no change was noted in these parameters. It was concluded that DIC could be induced by the intraperitoneal injection of topical thrombin only in cases of acute liver damages, where the increased permeability of peritoneum was postulated. However, such an immediate or marked change in coagulation was not found in our experiment as encountered in the clinical cases, which suggested the involvement of the anaphylactic reaction to the topical application of thrombin in the development of DIC in these clinical cases.
\end{abstract}

